\title{
KUALITAS LAPORAN KEUANGAN, ASIMETRI INFORMASI DAN EFISIENSI INVESTASI PADA PERUSAHAAN PERTAMBANGAN
}

\author{
Ida Ayu Candrasatyani Purba ${ }^{1}$ \\ I.G. Ngurah Agung Suaryana ${ }^{2}$ \\ ${ }^{1,2}$ Fakultas Ekonomi dan Bisnis Universitas Udayana, Bali, Indonesia \\ email: cdr.psatyani@gmail.com
}

\begin{abstract}
ABSTRAK
Penyajian laporan keuangan berkualitas dapat menyebabkan kegiatan investasi menjadi optimal terlebih lagi didukung oleh rendahnya asimetri informasi antara manajemen perusahaan dan pemegang saham. Tujuan riset adalah membuktikan secara empiris dan menjelaskan dampak laporan keuangan yang berkualitas pada asimetri informasi dan dampaknya pada efisiensi investasi. Objek penelitian yang digunakan adalah perusahaan tambang yang tercatat di Bursa Efek Indonesia tahun 2013-2015. Penentuan sampel menggunakan purposive sampling, dan diperoleh 69 sampel. Alat analisis menggunakan analisis jalur. Hasil diperoleh bahwa pengaruh kualitas laporan keuangan terhadap asimetri informasi bernilai negatif dan berpengaruh positif pada efisiensi investasi, asimetri informasi berpengaruh negatif pada efisiensi investasi, serta hanya sebagian asimetri informasi berperan memengaruhi kualitas laporan keuangan pada efisiensi investasi.
\end{abstract}

Kata kunci: Kualitas laporan keuangan, asimetri informasi, efisiensi investasi

\section{QUALITY OF FINANCIAL STATEMENTS, ASYMMETRY INFORMATION AND EFFICIENCY OF INVESTMENT IN MINING COMPANY}

\begin{abstract}
Presentation of qualified financial statements can lead to optimal investment activity, especially supported by the low information asymmetry between manager and shareholders. The research purposes to prove empirically and explain the impact of financial statements quality on information asymmetry and its impact on investment efficiency. Object of the research is mining companies listed on the Indonesia Stock Exchange year 2013-2015.Determination of the sample is purposive sampling, so that there are 69 companies sampled.Path analysis is a data analysis technique to obtain the results. The analysis result found that the quality of financial statement has a negative effect on information asymmetry and has a positive effect on investment efficiency, information asymmetry has a negative effect on investment efficiency, and only some of the information asymmetry contributes to the quality of the financial statements on investment efficiency.
\end{abstract}

Keywords: Quality of financial reports, information asymmetry, investment efficiency

DOI: https://doi.org/10.24843/JIAB.2018.v13.i01.p05

\section{PENDAHULUAN}

Kegiatan investasi di pasar modal sering dimanfaatkan oleh perusahaan dan investor demi menjaga dan mempertahankan keberlangsungan usaha serta memperoleh keuntungan yang ditargetkan. Mereka melakukan investasi melalui pasar modal. Investasi merupakan suatu kegiatan yang dilakukan dalam periode tertentu dengan tujuan mendapatkan return yang diharapkan (Ivan, 2013).
Manfaat investasi bagi perusahaan dan investor yaitu untuk memajukan keberlangsungan usaha dan mengembangkan modal (Virginia dkk., 2012). Pihakpihak yang melakukan investasi menginginkan agar biaya atau cost yang dikeluarkan lebih sedikit dibandingkan dengan tingkat pengembalian atau pendapatan yang diperoleh. Kegiatan investasi diharapkan berjalan secara efisien dan terhindar dari 
kondisi underinvestment yang melewatkan peluang investasi pada nilai NPV positif dan overinvestment yang memiliki kesempatan investasi relatif rendah (Sari dan Suaryana, 2014).

Laporan keuangan menyajikan informasi mengenai posisi keuangan sehingga dapat mengambil keputusan dengan tepat (Bushman dan Smith, 2001). Terlebih lagi jika laporan keuangan tersebut sudah dipublikasi sehingga dapat diketahui oleh khalayak umum (Pratiwiningsih, 2017). Perusahaan dinilai lebih siap menghadapi ketidakpastian jika telah dibekali dengan laporan keuangan yang berkualitas (Edvandini., dkk, 2014). Laporan keuangan yang memiliki kualitas tinggi dapat menjadi pedoman atau acuan yang baik untuk bisa menentukan dan kemudian menetapkan keputusan investasi yang optimal. Atas kondisi tersebut, maka manajemen perusahaan wajib menyusun laporan keuangan yang berkualitas karena merekalah yang diberikan wewenang penuh dari pemegang saham (pihak prinsipal) untuk mengelola kinerja perusahaan.

Penyajian laporan keuangan secara berkualitas berarti telah menunjukkan kondisi perusahaan yang sebenarnya sehingga dapat mengurangi asimetri informasi (Wang et. al., 2015). Perusahaan dituntut untuk menghasilkan laporan keuangan yang berkualitas dan didukung dengan rendahnya asimetri informasi (Tao Ma, 2012). Perusahaan yang telah menyusun laporan keuangan dengan baik, akan dapat meningkatkan keterbukaan yang semakin jelas kepada para pengguna laporan keuangan (Komalasari \& Permana, 2015). Penelitian Nurcholisah (2016), menunjukkan laporan keuangan yang berkualitas tidak berpengaruh pada asimetri informasi yang ada pada perusahaan dana pensiun.

Salah satu faktor kegiatan investasi menjadi kurang efisien yaitu adanya asimetri informasi yang dapat menyebabkan adanya persepsi berbeda antara manajemen perusahaan dengan pemegang saham. Satu sisi pihak prinsipal beranggapan bahwa laba yang dihasilkan tinggi, tetapi kondisi yang sesungguhnya ternyata laba yang dihasilkan tidak sebanding atas apa yang diharapkan. Manajemen perusahaan berusaha menutupi informasi dan cenderung berbuat curang demi memaksimumkan keuntungannya (Apriliani, 2012). Terciptanya efisiensi investasi jika adanya asimetri informasi yang rendah (Lingmin, 2013), Sedangkan Nurcholisah (2016) menyatakan asimetri informasi tidak memiliki pengaruh terhadap efisiensi investasi.

Semakin tinggi kualitas laporan keuangan maka kegiatan investasi yang dilakukan perusahaan makin efisien, karena sudah menunjukkan keadaan perusahaan yang memang benar adanya. Manajemen perusahaan akan bersifat akuntabel jika laporan keuangan sudah berkualitas sehingga memudahkan kesempatan berinvestasi (Bushman dan Smith, 2003). Laporan keuangan yang berkualitas akan memengaruhi perolehan informasi yang seimbang. Artinya, pemegang saham memperoleh informasi yang sama. Kualitas laporan keuangan melalui rendahnya asimetri informasi dapat memengaruhi efisiensi investasi. Menurut Amrullah dan Fatima (2015), semakin tinggi kualitas laporan keuangan yang disajikan, akan menurunkan perbedaan informasi sehingga berdampak pada kegiatan investasi kedepannya.

Sektor pertambangan merupakan salah satu

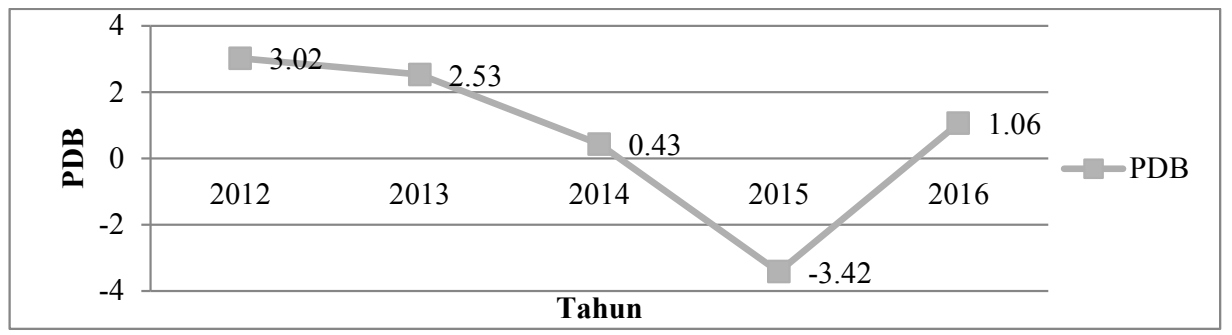

Gambar 1.

Laju Pertumbuhan PDB Sektor Pertambangan Tahun 2012-2016

Sumber: Data diolah, 2017

sektor yang menjadi sorotan dalam kegiatan investasi, karena dinilai mampu untuk memberikan sumber penerimaan yang cukup besar dan memegang kendali dalam sektor perekonomian di dunia. Pada tahun 2015, Indonesia meraih peringkat kelima sebagai produsen batubara terbesar di dunia, yaitu sebesar 241,1 Mt
(BP Statistical Review of World Energy, 2015). Tidak dapat dipungkiri dari tahun 2012-2015 laju pertumbuhan PDB sektor pertambangan di Indonesia mengalami penurunan, sedangkan di tahun 2016 mengalami peningkatan. Hal tersebut bisa disebabkan karena rendahnya minat dan keinginan para pemilik 
modal yang ingin berinvestasi. Rendahnya keinginan tersebut menyebabkan jumlah modal yang diperoleh perusahaan tambang sedikit, sehingga berimbas pada investasi yang dilakukan.

Data BPS menunjukkan bahwa laju pertumbuhan PDB sektor pertambangan tahun 2016 memberikan kontribusi pendapatan terendah dibandingkan dengan sektor lainnya. Melihat hal tersebut, ada kemungkinan bahwa investasi yang dilakukan oleh perusahaan pertambangan tidak maksimal, dikarenakan rendahnya tingkat pendapatan sehingga dinilai tidak mampu memberikan keuntungan yang besar.Jumlah pendapatan yang diperoleh perusahaan pertambangan dari tahun 2012-2016, akan berdampak pada kegiatan investasi kedepannya. Rendahnya pendapatan yang didapat, perusahaan dituntut agar lebih bertanggung jawab dalam menyajikan laporan keuangan yang berkualitas. Perusahaan harus bisa mengontrol minimnya tingkat pendapatan yang diperoleh dan tentu tidak adanya informasi yang disembunyikan oleh manajemen perusahaan. Perbedaan informasi yang terjadi dari pihak agen dengan pihak prinsipal, merupakan salah satu pemicu terbatasnya investasi yang dilakukan perusahaan. Terlebih lagi dengan melihat kondisi keuangan perusahaan yang sangat minim. Berdasarkan fenomena diatas, maka rumusan masalah penelitianyang akan diteliti yaitu apakah laporan keuangan yang berkualitas berpengaruh terhadap tingkat asimetri informasi (information asymmetry) dan efisiensi investasi, serta apakah asimetri informasi berdampak pada efisiensi investasi, dan apakah laporan keuangan yang berkualitas berdampak tak langsung pada efisiensi investasi.

Manfaat teoritis yang dapat diberikan yaitu sesuai dengan teori keagenan, adanya perbedaan kepentingan dapat memicu masalah keagenan.Upaya yang dapat dilakukan yaitu dengan meningkatkan penyajian laporan keuangan sehingga tidak adanya perbedaan informasi dan kegiatan investasi menjadi lebih efisien. Manfaat praktis penelitian ini bagi perusahaan, pemegang saham, dan regulator.

Teori keagenan mencerminkan hubungan yang mengikat antara pihak agen dan pihak prinsipal, dimana pihak prinsipal memberikan kewenangan kepada pihak agen atas nama prinsipal (Jensen dan Meckling, 1976). Tidak dapat dipungkiri dari adanya kontrak tersebut, kedua belah pihak berusaha untuk memaksimalkan kepentingannya masing-masing sehingga menimbulkan masalah keagenan. Pihak agen berkesempatan untuk merahasiakan terkait dengan kondisi perusahaan kepada pihak prinsipal. Pihak agen dapat melakukan hal tersebut karena mereka lebih banyak memiliki keleluasan untuk bisa memanipulasi laporan keuangan dan secara sengaja menutup-nutupi informasi penting kepada pihak prinsipal (Jensen dan Meckling, 1976).

Pihak prinsipal tentu merasa sangat dirugikan karena mereka telah menaruh kepercayaan penuh kepada pihak agen untuk mengelola perusahaan tanpa adanya sesuatu yang disembunyikan. Hal tersebut nantinya akan sangat berdampak apabila perusahaan melakukan kegiatan investasi, seperti menambah jumlah peralatan atau investasi untuk jangka panjangnya (Jensen dan Meckling, 1976). Melihat perbedaaan kepentingan dan askses terhadap informasi, upaya yang dapat dilakukan yaitu dengan menyajikan laporan keuangan yang berkualitas sehingga tercipta efisiensi investasi yangakan memberikan keuntungan bagi perusahaan (Sari dan Suaryana, 2014). Terciptanya efisiensi investasi apabila perusahaan mampu mengalokasikan modal dengan baik serta mampu mengidentifikasi keputusan investasi yang tepat (Sari dan Suaryana, 2014). Pengidentifikasian keputusan investasi sangat diperlukan karena dapat menentukan nasib perusahaan di masa yang akan datang. Berdasarkan beberapa penjelasan diatas maka peneliti merumuskan kerangka konseptual penelitian sebagai berikut.

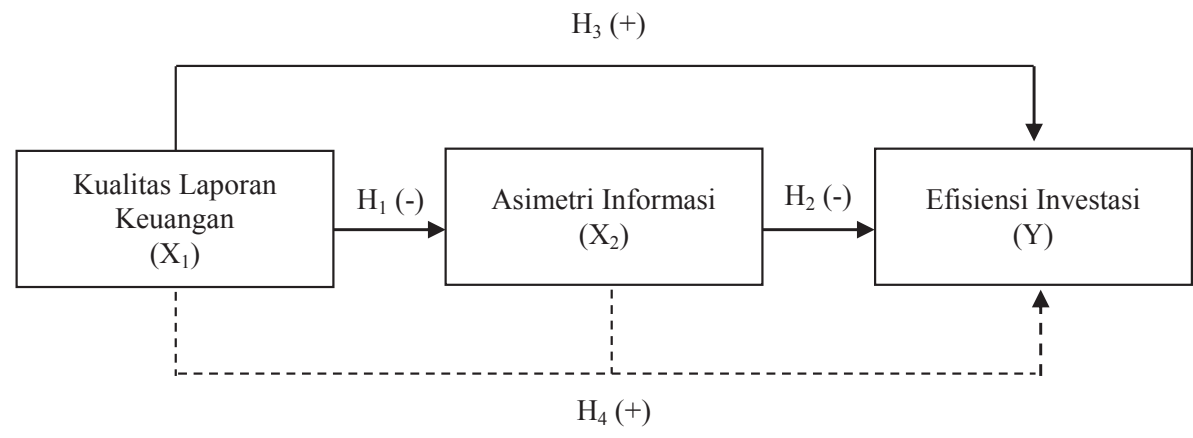

Gambar 2. Model Penelitian 
Perusahaan yang telah menyajikan laporan keuangan yang berkualitas dapat dengan mudah mengetahui kinerja perusahaan.Rendahnya asimetri informasi itu berarti bahwa laporan keuangan telah disajikan secara berkualitas sehingga tidak adanya ketidakseimbangan informasi. Semakin kecil perbedaan informasi berarti pemegang saham telah melakukan pengawasan secara efektif terhadap kinerja yang dilakukan oleh manajemen perusahaan. Manajemen perusahaan telah mendapat pantauan langsung dari pemegang saham sehingga laporan keuangan yang disajikan menjadi lebih berkualitas.

Hasil temuan oleh Francis et. al., (2005), Cohen (2006), Setiany dan Wulandari (2015), dan Fanani (2009), bahwa semakin tinggi kualitas laporan keuangan akan mampu untuk mengurangi perbedaan informasi. Terdapat perbedaan dengan penelitian yang dilakukan oleh Indriani dan Khoiriyah (2010), dimana kualitas laporan keuangan yang terdiri dari relevant, timelines, dan conservatism berpengaruh positif pada asimetri informasi. Tidak adanya hubungan antara kualitas laporan keuangan pada asimetri informasi (Santoso, 2012 dan Kusuma., dkk, 2014).

Kegiatan investasi menjadi efisien apabila informasi yang diperoleh oleh pihak manajemen perusahaan dan pemegang saham seimbang. Hal tersebut menyebabkan sedikit kemungkinan bagi pihak manajemen perusahaan untuk melakukan tindakan manipulasi laporan keuangan. Terciptanya efisiensi investasi apabila perusahaan tidak melakukan investasi diatas atau dibawah tingkat optimal (Bushman et al. 2011). Menurut Lingmin (2013), rendahnya asimetri informasi menyebabkan tingginya kondisi overinvestment dan semakin rendahnya kondisi underinvestment. Penelitian yang dilakukan oleh Nurcholisah (2016), menunjukkan asimetri informasi tidak berpengaruh pada efisiensi investasi.

Salah satu indikator keberhasilan kegiatan investasi yaitu laporan keuangan yang bermutu. Menurut Butar (2015), jika terjadi overinvestment, perusahaan dapat mengurangi investasi apabila laporan keuangan telah disajikan secara berkualitas. Kondisi overinvestment menggambarkan bahwa banyaknya investasi yang dilakukan, tetapi perusahaan hanya sedikit memperoleh keuntungan. Kegiatan investasi yang efisiendapat ditingkatkan apabila, antara kualitas laporan keuangan dengan efisiensi investasi berhubungan positif (Putri, 2014). Sementara menurut Setyawati (2015), tidak adanya pengaruh antara kualitas laporan keuangan terhadap efisiensi investasi.Tingginya tingkat kualitas laporan keuanganbisa meringankan perusahaan dalam mengambil keputusan berinvestasi karena mampu untuk menurunkan asimetri informasi. Kedua belah pihak yaitu manajer dan shareholders telah mendapat informasi seimbang terkait kondisi perusahaaan, yang sudah tercermin pada laporan keuangansehingga tercipta investasi yang efisien melalui rendahnya kesenjangan informasi. Hal tersebut berarti bahwa tidak adanya informasi yang disembunyikan lagi oleh manajemen perusahaan karena sudah tercermin dari laporan keuangan yang berkualitas. Kecilnya asimetri informasi dapat mengakibatkan investasi yang dijalankan perusahaan menjadi efisien. Penelitian Amrullah dan Fatima (2015) menunjukkan bahwa kualitas laporan keuangan dapat menekan perbedaan informasi, sehingga dapat menurunkan inefisiensi investasi.

Berdasarkan penjelasan dan penjabaran diatas, maka hipotesis yang dapat ditarik yakni memiliki pengaruh yang negatif antara kualitas laporan keuangan terhadap asimetri informasi $\left(\mathrm{H}_{1}\right)$, memiliki dampak yang negatif antara asimetri informasiterhadap efisiensi investasi $\left(\mathrm{H}_{2}\right)$, memiliki pengaruh yang positif antara kualitas laporan keuangan pada efisiensi investasi $\left(\mathrm{H}_{3}\right)$, serta memiliki pengaruh secara tidak langsung kualitas laporan keuangan pada efisiensi investasi $\left(\mathrm{H}_{4}\right)$.

\section{METODE PENELITIAN}

Jenis data yakni data kuantitatif tahun 2013-2015 yang tercatat oleh BEI bersumber pada perusahaan pertambangan. Purposive sampling sebagai teknik penentuan sampel. Terdapat beberapa syarat yang harus terpenuhi, yaitu perusahaan pertambangan yang menyajikan laporan keuangan auditan tiap tahunnya serta menyajikan secara lengkap informasi yang dibutuhkan dalam penelitian. Bersumber pada syarat tersebut, diperoleh 69 sampel untuktiga tahun pengamatan.Penelitian ini menggunakan analisis jalur yang mengacu pada model milik Solimun (2010).

Menurut Solimun (2010), terdapat dua cara yang bisa digunakan untuk menganalisis path analysis, yaitu dengan metode perbedaan koefisien dan metode perkalian koefisien. Penelitian ini memilih menggunakan metode perbedaan koefisien. Langkahlangkah yang dilakukan, pertama, tanpa melibatkan asimetri informasi sebagai variabel mediasi untuk menguji pengaruh kualitas dari suatu laporan keuangan pada efisiensi investasi. Langkah kedua, yakni dengan melibatkan mediasi yaitu dengan memasukkan asimetri informasi. 

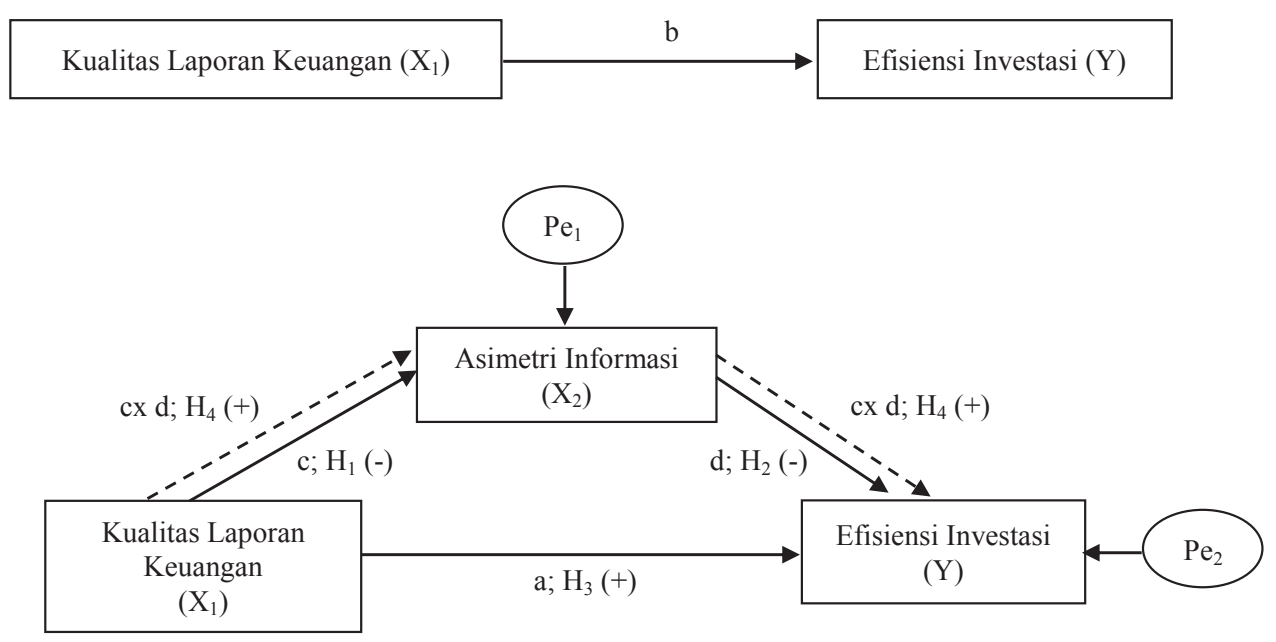

Gambar 3.

Model Diagram Jalur

Sumber: Data diolah, 2017

Model diagram jalur juga dapat dinyatakan ke dalam bentuk persamaan yaitu sebagai berikut:

$\mathrm{X}_{2}=\mathrm{X}_{\mathrm{c}}+\varepsilon$

$\mathrm{Y}=\mathrm{X}_{1}+{ }_{\mathrm{d}} \mathrm{X}_{2}+\varepsilon_{2}$

Penjelasan:

$\mathrm{X}_{1} \quad=$ Kualitas laporan keuangan

$\mathrm{X}_{2} \quad=$ Asimetri informasi

$\mathrm{Y}^{2} \quad=$ Efisiensi investasi

$\mathrm{a}, \mathrm{b}, \mathrm{c}, \mathrm{d}=$ Standarisasi koefisien regresi

$\mathrm{P} \varepsilon_{1}, \mathrm{P} \varepsilon_{2}=$ Error

Berdasarkan Gambar 2, asimetri informasi mengambil penuh peran variabel bebas apabila pengaruh variabel bebas ke variabel intervening dan nilai variabel intervening ke variabel terikat signifikan, tetapi pengaruh variabel bebas ke variabel terikat tidak signifikan. Asimetri informasi dikatakan sebagai variabel intervening sebagian, apabila pengaruh variabel bebas ke variabel intervening dan nilai variabel mediasi (intervening) ke variabel terikat (dependen) signifikan, serta pengaruh variabel bebas (independen) ke variabel terikat (dependen) juga signifikan, dimana koefisien nilai variabel bebas (independen) ke variabel terikat (dependen) lebih kecil dari besaran variabel bebas ke variabel terikat (sebelum adanya variabel intervening).

Asimetri informasi dikatakan bukan sebagai variabel intervening, jika pengaruh variabel bebas ke variabel intervening dan nilai variabel intervening (mediasi) ke variabel terikat (dependen) signifikan, serta pengaruh variabel bebas (independen) kevariabel terikat (dependen) juga signifikan, dimana koefisien pengaruh variabel bebas ke variabel terikat hampir sama dengan pengaruh variabel bebas ke variabel terikat (sebelum adanya variabel intervening) serta nilai pengaruh variabel bebas ke variabel intervening dan nilai variabel intervening ke variabel terikat (atau keduanya) tidak signifikan (Solimun, 2010).

Menurut Biddle et. al., (2009) efisiensi investasi diukur dengan model investasi yang menggambarkan kesempatan pertumbuhan, yang kemudian didapat residual value dimana nantinya dijadikan nilai pada saatpengukuran variabel tersebut. Berikut ini disajikan model pengukuran dari efisiensi investasi.

Investmenti $_{, \mathrm{t}+1}=\beta_{0}+\beta_{1} *$ Sales Growth ${ }_{i, \mathrm{t}}+\varepsilon_{\mathrm{i}, \mathrm{t}+1}$

Keterangan:

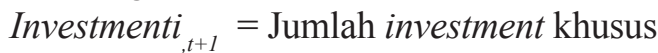
fixed asset.

Sales Growth $_{i, t}=$ Tingkat sales tahun dikurang dengan sales $s_{t-1}$ dibagi dengan sales $_{t-1}$.

Semakin relevannya informasi laba dalam laporan keuangan dapat digunakan perkiraandalam mengalokasikan modal (Nurwa dan Purwanto, 2015). Laporan keuangan yang memiliki tingkat akrual tinggi mencerminkan manajemen perusahaan melakukan tindakan perekayasaan laba (Dechow dan Dichev, 2002). Abnormal akrual yang merupakan bagian dari kualitas akrual digunakan untuk mengukur variabel dari kualitas laporan keuangan yang mengacu pada model Kothari et. al., (2005), yang dapat dijabarkan pada persamaan dibawah ini: 
$\begin{aligned} T A_{i, t}= & a_{0}+a_{1}\left[1 / \operatorname{ASSETS}_{i, t-1}\right]+a_{2} \Delta \operatorname{SALES}_{i, t}+ \\ & a_{3} \operatorname{PCPE}_{i, t}+a_{4} \operatorname{ROA}_{i, t(\text { or } i, t-1)}+\varepsilon_{i, t} \ldots \ldots \ldots \ldots \ldots \ldots \ldots \ldots \ldots\end{aligned}$

Adapun perhitungan dari masing-masing variabel dari kualitas dari suatu laporan keuangan yakni:

$\begin{aligned} T A_{i, t} \quad= & \text { Laba Bersih }- \text { Arus Kas } \\ & \text { dari Aktivitas Operasi... }\end{aligned}$

$\triangle S A L E S_{i, t}=$ Penjualan $_{\mathrm{t}}-$ Penjualan $_{\mathrm{t}-1}$

$R O A_{i, t}{ }^{l, t}=\frac{\text { Laba Bersih }}{\text { Total Aset }}$

$P P E_{i, t} \quad=$ Penerimaan Aktiva Tetap Penyusutan Aktiva Tetap.

Berdasarkan persamaan di atas, akan didapat residual value yang dipakai dalam mengukur seberapa berkualitasnya laporan keuangan tersebut. Residual value dapat dicari dengan membagi ASSETS $_{i, t-1}$ disetiap variabel, dengan rumus yaitu:

$$
\begin{aligned}
\text { Residual Value }= & \frac{T A_{i, t}}{\operatorname{ASSETS}_{i, t-1}}-\frac{\Delta \text { SALES }_{i, t}}{\operatorname{ASETSS}_{i, t-1}}- \\
& \frac{\operatorname{PPE}_{i, t}}{\operatorname{ASSETS~}_{i, t-1}}-\frac{\operatorname{ROA}_{i, t}}{\operatorname{ASSETS}_{i, t-1}} \ldots \ldots . .(9)
\end{aligned}
$$

Leuz dan Verrecchia (2000) menjabarkan bahwa secara umum bahwa bid-ask spread dapat dijadikan sebagai bahan pengukuran dari asimetri informasi. Bid-ask spread berhubungan dengan harga penawaran dan permintaan saham di pasar modal (Howe dan Lin, 1992). Semakin kecil perbedaan nilai bidask spread, berarti keduanya (shareholders dan manajer) telah memiliki informasi yang seimbang terkait dengan harga permintaan terendah dan harga penawaran tertinggi. Tingginya ketimpangan informasi mencerminkan bahwa tingginya besaran selisih harga penawaran dan permintaan Berikut ini rumus untuk memperoleh nilai spread dari asimetri informasi.

$S P_{i, t}=\frac{\left(A P_{i, t}-B P_{i, t}\right)}{\left(\left(A P_{i, t}+B P_{i, t}\right) / 2\right)}$

Keterangan:

$S P_{i, t} \quad=$ Selisih harga penawaran dengan harga permintaan.

$A P_{i, t} \quad=$ Harga penawaran tertinggi saham perusahaan.

$B P_{i, t} \quad=$ Harga permintaan terendah saham perusahaan.

\section{HASIL DAN PEMBAHASAN}

Pembahasan pertama menjelaskan terlebih dahulu mengenai pemeriksaan statistik deskriptif tentang besaran mean atau rata-rata, data yang memiliki nilai rendah (minimum), data yang memiliki nilai tinggi (maksimum), dan standard deviation. Setelah itu dijelaskan hasil uji asumsi klasik dan penjelasan terakhir mengenai hasil analisis jalur yang mengacu model Solimun (2010). Metode perbedaan koefisien dipilih untuk memeriksa apakah variabel yang digunakan mampu untuk memediasi atau dapat dijadikan perantara antar variabel bebas ke terikatnya.Pengujian melalui metode perbedaan koefisien dilakukan dengan memerhatikan besaran nilai koefisien serta apakah nilainya signifikan atau tidak.

Berdasarkan data di tabel 1, besaran nilai mean asimetri informasi yaitu 0,023 , nilai minimum yakni 0,000 , nilai maksimum ialah 0,087 , dan standar deviasi bernilai 0,022. Kualitas laporan keuangan

Tabel 1.

\begin{tabular}{|c|c|c|c|c|}
\hline & & $\begin{array}{l}\text { Kualitas } \\
\text { Lap. Keu }\end{array}$ & $\begin{array}{l}\text { Asimetri } \\
\text { Info. }\end{array}$ & Efisiensi Invest. \\
\hline \multirow[t]{2}{*}{$\mathrm{N}$} & Valid & 69 & 69 & 69 \\
\hline & Missing & 0 & 0 & 0 \\
\hline Mean & & 0,300 & 0,023 & 1637679606,199 \\
\hline Std Error of Mean & & 0,026 & 0,003 & 37171902,900 \\
\hline Median & & 0,277 & 0,020 & 1525911574,000 \\
\hline Mode & & 0,100 & 0,000 & 2421674320,310 \\
\hline Std. Deviation & & 0,212 & 0,022 & 308773015,663 \\
\hline Variance & & 0,045 & 0,000 & 95340775201897800,000 \\
\hline Range & & 0,881 & 0,087 & 1174054382,310 \\
\hline Minimum & & 0,015 & 0,000 & 1247619938,000 \\
\hline Maximum & & 0,896 & 0,087 & 2421674320,310 \\
\hline
\end{tabular}

Pengujian Analisis Statistik Deskriptif

Sumber: Data diolah, 2017 
mempunyai nilai mean 0,300 , nilai minimum 0,015 , nilai maksimum 0,896 , dan nilai standar deviasi 0,212 . Nilai mean efisiensi investasi yaitu
1637679606,199, nilai minimum 1247619938,000, nilai maksimum 2421674320,310 , dan nilai standar deviasi 308773015,663.

Tabel 2.

Pengujian Normalitas

\begin{tabular}{llr}
\hline & & $\begin{array}{c}\text { Unstandardized } \\
\text { Residual }\end{array}$ \\
\hline $\mathrm{N}$ & & 69 \\
Normal Parameters & & 0,035 \\
& Mean & 1,028 \\
Most Extreme & Std. Deviation & 0,115 \\
Differences & Absolute & 0,115 \\
& Positive & $-0,072$ \\
Kolmogorov-Smirnov Z & Negative & 0,957 \\
Asymp. Sig. (2-tailed) & & 0,319 \\
\hline
\end{tabular}

Sumber: Data diolah, 2017

Hasil pengujian normalitas, dapat dikatakan bahwa data telah berdistribusi normal, karena nilai $0,319>0,05$.

Berdasarkan hasil uji autokorelasi regresi substruktur 1 nilai $\mathrm{dw}=1,833$ terletak diantara $\mathrm{du}=$ 1,64 dan 4-dU $=2,36$, berarti data diatas terbebas dari pengaruh autokorelasi.

Berdasarkan hasil uji autokorelasi regresi substruktur 2 nilai $\mathrm{dw}=1,789$ terletak diantara du $=1,67$ dan $4-\mathrm{dU}=2,33$, berarti tidak mengandung gejala autokorelasi.

Pengujian multikolinearitas hanya dilakukan untuk regresi substruktur 2 yang mempunyai lebih dari dua variabel bebas, sehingga tidak memerlukan pengujian untuk regresi substruktur 1 .

Berdasarkan uji multikolinearitas regresi substruktur 2 nilai tolerance $=0,941>0,1$ dan $\mathrm{VIF}=1,063<10$, sehingga terbebas dari gejala multikolinearitas.

Hasil uji heteroskedastisitas regresi substruktur 1, variabel konstan yakni kualitas laporan yang diregresikan dengan asimetri informasi sebagai variabel dependen, memiliki nilai signifikansi $=0.055$ $>0,05$, berarti terbebas dari gejala heteroskedastisitas.

Variabel kualitas laporan keuangan memiliki nilai signifikansi $=0,227>0,05$ dan variabel asimetri informasi memiliki nilai signifikansi $=0,071>0,05$, berarti terbebas dari gejala heteroskedastisitas.

Berdasarkan pengujian Hasil Uji Linieritas 1 dan 2, nilai signifikansi model linier pertama sebesar $0,044<0,05$, sedangkan nilai signifikansi model linier kedua sebesar $0,010<0,05$. Pengujian menggunakan Curve Fit jika nilai signifikansi model linier $<0,05$, berarti asumsi linieritas terpenuhi.

Berdasarkan pengujian Pengujian Path Analysis (Regresi Substruktur 1 dan 2), maka persamaan yang dapat dibentuk adalah sebagai berikut:

$\mathrm{X}_{2}=0,243 \mathrm{X}_{1}+\varepsilon_{1}$

$\mathrm{Y}=0,313 \mathrm{X}_{1}+0,231 \mathrm{X}_{2}+\varepsilon_{2}$

Besarnya nilai koefisien pengaruh kualitas laporan keuangan terhadap efisiensi investasi sebelum adanya intervening (b), yaitu sebesar 0,369.

Tabel 3.

Hasil Uji Autokorelasi Regresi Substruktur 1

\begin{tabular}{cccccc}
\hline Model & $\mathrm{R}$ & R Square & $\begin{array}{c}\text { Adjusted R } \\
\text { Square }\end{array}$ & $\begin{array}{c}\text { Std. Error of the } \\
\text { Estimate }\end{array}$ & Durbin-Watson \\
\hline 1 & $0,243^{\mathrm{a}}$ & 0,059 & 0,045 & 0,977 & 1,833 \\
\hline
\end{tabular}

Sumber: Data diolah, 2017

Berdasarkan hasil uji autokorelasi regresi substruktur 1 nilai $\mathrm{dw}=1,833$ terletak diantara $\mathrm{du}=1,64$ dan 4-dU $=2,36$, berarti data diatas terbebas dari pengaruh autokorelasi.
Berdasarkan uji multikolinearitas regresi substruktur 2 nilai tolerance $=0,941>0,1$ dan $\mathrm{VIF}=1,063<10$, sehingga terbebas dari gejala multikolinearitas. 
Berikut hasil perhitungan dari nilai koefisien pengaruh kualitas laporan keuangan terhadap efisiensi investasi sebelum adanya intervening yang ada pada Tabel 4.

Tabel 4.

Nilai Koefisien Pengaruh Kualitas Laporan Keuangan padaEfisiensi Investasi Sebelum Adanya Intervening

\begin{tabular}{llrrrrr}
\hline & \multicolumn{7}{c}{ Unstandardized } & \multicolumn{2}{c}{ Standardized } \\
Coefficients & Coefficients & \\
Model & & B & Std. Error & Beta & \multicolumn{1}{c}{ t } & \multicolumn{1}{c}{ Sig. } \\
\hline 1 & (Constant) & $-0,076$ & 0,074 & & $-1,035$ & 0,305 \\
& Kualitas Lap. Keu & 0,206 & 0,063 & 0,369 & 3,254 & 0,002 \\
\hline $\mathrm{R}^{2}$ & $: 0,136$ & & & & & \\
Adjusted R $^{2}$ & $: 0,124$ & & & & & \\
F Statistik & $: 10,590$ & & & & & \\
Sig. & $: 0,002$ & & & & & \\
\hline
\end{tabular}

Sumber: Data diolah, 2017

Sebelum melakukan interpretasi hasil, terlebih dahulu dilakukan pemeriksaan validitas model yang diperolehmelalui dua macam metode yakni dengan koefisien determinasi total dan pembuangan jalur yang tidak diperlukan. Perhitungan nilai standard error ialah langkah pertama sebelum mendapatkan nilai R2M, yang dirumuskan dengan:

$\mathrm{P}_{\mathrm{ei}}=\sqrt{1-R^{2}}$

$\mathrm{P}_{\mathrm{e} 1}=\sqrt{1-0,059}=0,97$

$\mathrm{P}_{\mathrm{e} 2}=\sqrt{1-0,187}=0,90$
Maka, nilai yang didapat untuk koefisien determinasi total $\left(\mathrm{R}^{2} \mathrm{M}\right)$ ialah:

$\mathrm{R}^{2} \mathrm{M}=1-\left(\mathrm{Pe}_{1}\right)^{2}\left(\mathrm{Pe}_{2}\right)^{2} \ldots\left(\mathrm{Pe}_{\mathrm{p}}\right)^{2}$.

$\mathrm{R}^{2} \mathrm{M}=1-\left(\left(0,97^{2}\right)\left(0,90^{2}\right)\right)$

$\mathrm{R}^{2} \mathrm{M}=0,237$

Koefisien determinasi total sebesar 0,237 berarti sejumlah 0,237 persen informasi yang terdapat mampu diterangkan dengan model itu, sementara 0,763 persen diterangkandengan variabel lain yang ada diluar model tersebut. Penelitian ini tidak mengalami pembuangan jalur, karena masingmasing pengaruh variabel telah memiliki nilai yang signifikan, yaitu kurang dari 0,05 .

Tabel 5.

Ringkasan Pengaruh Masing-masing Variabel

\begin{tabular}{llcl}
\hline Pengaruh Variabel & $\begin{array}{c}\text { Pengaruh } \\
\text { Langsung (a) }\end{array}$ & $\begin{array}{c}\text { Pengaruh Tidak } \\
\text { Langsung (melalui } \\
\text { Asimetri Informasi) } \\
(\mathrm{c} \mathrm{x} \mathrm{d})\end{array}$ & $\begin{array}{c}\text { Pengaruh Total (a } \\
+(\mathrm{c} \mathrm{x} \mathrm{d}))\end{array}$ \\
\hline $\mathrm{KLK} \rightarrow$ EI & $\mathrm{a}=0,313$ & 0,0561 & 0,369 \\
$\mathrm{KLK} \rightarrow$ AI & $\mathrm{c}=0,243$ & & 0,243 \\
$\mathrm{AI} \rightarrow$ EI & $\mathrm{d}=0,231$ & & 0,231 \\
\hline
\end{tabular}

Sumber: Data diolah, 2017

Sesuai dengan analisis path dapat diketahui bahwa, pertama ialah pengaruh kualitas laporan keuangan $\left(\mathrm{X}_{1}\right)$ terhadap efisiensi investasi (Y) memiliki nilai memiliki nilai signifikansi atau sig $\mathrm{t}$ sebesar 0.008 . Nilai sig t $0,008<0,05$, dapat diartikan adadampak langsung variabel independen (bebas) 
terhadap variabel dependen (terikat).Kedua, ialah pengaruh kualitas laporan keuangan $\left(\mathrm{X}_{1}\right)$ terhadap asimetri informasi $\left(\mathrm{X}_{2}\right)$ memiliki nilai signifikansi atau sig t sebesar 0,044. Nilai sig t 0,044<0,05, memperlihatkan adanya pengaruh langsung antara variabel independen (bebas) dengan variabel mediasi.Ketiga, ialah pengaruh asimetri informasi $\left(\mathrm{X}_{2}\right)$ terhadap efisiensi investasi $(\mathrm{Y})$ memiliki nilai memiliki nilai signifikansi atau sig t sebesar 0,047. Nilai sig t $0,047<0,05$, menerangkan jika ada pengaruh langsung antara variabel mediasi dengan variabel dependen.

Pengajuan hipotesis pertama yaitu kualitas laporan keuangan berpengaruh negatif pada asimetri informasi. Berdasarkan hasil analisis jalur, koefisien regresi standar sebesar 0,243 (sig $=0,044<0,05)$, berarti $H_{1}$ sesuai, yaitu pengaruh negatif antara kualitas dari suatu laporan keuangan pada asimetri informasi. Tingginya tingkat kualitas dari laporan keuangan mampu menekan perbedaan informasi. Sedikitnya perbedaan informasi yang diperoleh, artinya pihak prinsipal yaitu pemegang saham sudah melakukan tanggungjawabnya untuk memberikan pengawasan ataupun pemeriksaan terhadap kinerja yang dilakukan oleh pihak agen, yakni manajemen perusahaan. Menurut Cohen (2006), semakin berkualitasnya laporan keuangan maka akan berdampak pada rendahnya perbedaan informasi. Perusahaan yang telah menyajikan laporan keuangan yang berkualitas maka asimetri informasi dapat dikurangi (Setiany dan Wulandari, 2015 dan Fanani, 2009). Manajemen perusahaan tidak bisa menyembunyikan informasi penting terkait dengan kondisi perusahaan karena sudah tercermin dari pengungkapan laporan keuangan yang memiliki kualitas tinggi.

Hipotesis kedua menyatakan asimetri informasi memiliki pengaruh negatif pada efisiensi investasi. Berdasarkan hasil analisis jalur, koefisien regresi standar sebesar 0,231 ( $\mathrm{sig}=0,047<0,05)$, berarti $\mathrm{H}_{2}$ diterima, yaitu asimetri informasi berpengaruh negatif pada efisiensi investasi. Penelitian ini sejalan dengan penelitian Lingmin (2013), yaitu rendahnya asimetri informasi menyebabkan tingginya kondisi overinvestment dan semakin rendahnya kondisi underinvestment. Semakin rendahnya asimetri informasi, maka investasi yang dilakukan akan menjadi efisien dan lebih optimal. Hal ini berarti tidak adanya informasi yang sengaja untuk disembunyikan sehingga kegiatan investasi menjadi efisien. Perusahaan bisa menetapkan pilihan investasi yang tepat sesuai dengan tingkat kemampuan dan ketersediaan modal.

Hipotesis ketiga menyatakan bahwa kualitas laporan keuangan berdampak secara positif pada efisiensi investasi. Berdasarkan hasil analisis jalur, koefisien regresi standar sebesar 0,313 ( $\mathrm{sig}=0,008$ $<0,05$ ), berarti $\mathrm{H}_{3}$ diterima, yaitu kualitas laporan keuangan berpengaruh positif pada efisiensi investasi. Sepemikiran dengan penelitian yang dilakukan oleh Butar (2015), yaitu laporan keuangan dapat menurunkan investasi jika terjadi overinvestment. Menurut Biddle dan Hilary (2006) dan McNichols dan Stubben (2008), tingginya tingkat kualitas laporan keuangan dapat memudahkan bagi perusahaan untuk mengalokasikan modal sehingga investasi yang dilakukan menjadi lebih efisien.

Kegiatan investasi dapat dikatakan efisien jika perusahaan telah menyajikan laporan secara berkualitas. Laporan keuangan yang telah disusun secara berkualitas dapat membantu perusahaan ketika dihadapkan pada kondisi ketidakoptimalan investasi (Gomariz dan Ballesta, 2013 dan Chen et. al., 2011). Menurut Rahmawati dan Harto (2014), Putri (2014), dan Sakti dan Septiani (2015) menunjukkan terdapat hubungan yang positif antara pengaruh tingkat kualitas dari laporan keuangan suatu perusahaan terhadap investasi yang efisien.

Secara tidak langsung kualitas dari laporan keuangan berpengaruh pada efisiensi investasi melalui perantara minimnya perbedaan informasi. Pengujian hipotesis keempat mengacu pada model yang digunakan oleh Solimun (2010). Hasil perhitungan sebelumnya didapat nilai koefisien $\mathrm{a}=$ $0,313$ (sig $a=0,008)$, nilai koefisien $b=0,369$ (sig $b$ $=0,002)$, nilai koefisien $\mathrm{c}=0,243(\mathrm{sig} \mathrm{c}=0,044)$, dan nilai koefisien $\mathrm{d}=0,231$ ( $\operatorname{sig} d=0,047)$. Berdasarkan hasil tersebut, asimetri informasi dikatakan sebagai variabel intervening sebagian yaitu hanya sebagian pengaruh efisien investasi dipengaruhi oleh asimetri informasi.Sejalan dengan penelitian dari Amrullah dan Fatima (2015), dimana kualitas laporan keuangan dapat menekan perbedaan informasi sehingga tercipta efisiensi investasi. Melalui rendahnya asimetri informasi, secara tidak langsung dapat menumbuhkan efisiensi investasi karena perusahaan sudah menyusun laporan keuangan berdasarkan kondisi sebenarnya. Penelitian diatas telah lulus uji ( Pengujian Analisis Statistik Deskriptif, Pengujian Normalitas, Hasil Uji Autokorelasi Regresi Substruktur, Hasil Uji Multikolinearitas Regresi Substruktu, Hasil Uji Heteroskedastisitas Regresi Substruktur, Hasil Uji Linieritas, Pengujian Path Analysis, Nilai Koefisien Pengaruh Kualitas Laporan Keuangan pada Efisiensi 
Investasi Sebelum Adanya Intervening, dan Ringkasan Pengaruh Masing-masing Variabel).

\section{SIMPULAN}

Setelah melakukan pengujian terhadap data yang telah dijabarkan, dapat ditarik simpulan penelitian yaitu perusahaan yang telah membuat laporan keuangan yang berdaya kualitas tinggi dapat meminimalkan asimetri informasi.Penekanan asimetri informasi yang rendah, membuat kegiatan investasi menjadi efisien karena perusahaan telah mendapat keuntungan yang maksimal.Investasi dapat berjalan efisien jika perusahaan telah menyediakan laporan sesuai dengan kondisi keuangan yang sebenarnya. Semakin tinggi kualitas suatu laporan maka dapat meningkatkan investasi, serta hanya sebagian pengaruh kualitas laporan keuangan pada efisiensi investasi dipengaruhi oleh asimetri informasi.

Memperluas obyek penelitian dengan cara menambah beberapa variabel bebas yang dinilai tepat dalam penelitian disarankan untuk penelitian selanjutnya. Saran lain yang dapat diberikan yaitu dengan menggunakan sampel yang lebih luas dan tidak terpaku pada satu sektor tertentu.

Terdapat dua implikasi yang didapatkan dari hasil penelitian ini, yaitu implikasi teoritis dan implikasi praktis. Penelitian menyatakan bahwa dengan kualitas laporan keuangan yang tinggi memiliki pengaruh bernilai negatif pada information asymmetry, asimetri informasi berdampak negatif pada efisiensi investasi, serta hubungan yang positif antara kualitas laporan keuangan pada efisiensi investasi, dan secara tak langsung kualitas laporan keuangan memiliki pengaruh dengan efisiensi investasi melalui asimetri informasi yang kecil.

Berdasarkan hasil penelitian tersebut, sejalan dengan teori yang dipakai, dimana kaitan shareholders dengan manajer perusahaan dapat menumbuhkan kesenjangan informasi. Manajer bertugas untuk mengelola perusahaan lebih banyak mengetahui informasi sehingga lebih bebas untuk memengaruhi dan merekayasa pelaporan keuangan demi memaksimalkan kepentingannya. Akibat adanya kondisi asimetri informasi tersebut, maka pihak agen dapat memengaruhi kualitas laporan keuangan yang akan berdampak pada efisiensi investasi.

Sementara, implikasi secara praktis akan berimplikasi pada perusahaan itu sendiri yaitu perusahaan pertambangan, pemegang saham, maupun regulator. Hasil penelitian membuktikan kualitas laporan keuangan dan kesenjangan informasi memengaruhi efisiensi investasi. Demi terwujudnya investasi yang efektif, perusahaan perlu menyajikan laporan keuangan yang berkualitas. Secara tak langsung ternyata perusahaan yang telah mengungkapkan laporan keuangan yang memiliki kualitas tinggi dapat memaksimumkan tingkat efisiensi investasi melalui minimnya information asymetry antara manajer dengan pemegang saham. Implikasi bagi pemegang saham, yakni dapat menjadi pertimbangan bagi pemegang saham untuk mengambil keputusan investasi agar menjadi efisien yang tercermin berdasarkan pada penyajian laporan keuangan yang berkualitas, karena laporan yang berkualitas menunjukkan kondisi perusahaan sesungguhnya dimana tidak ada informasi yang disembunyikan oleh manajemen perusahaan. Implikasi untuk regulator sendiri adalah sebagai bahan pertimbangan untuk membuat regulasi terkait dengan penyampaian laporan keuangan yang memiliki tingkat kualitas tinggi, dengan tujuan agar bisa mengurangi asimetri informasi yang tentu berimplikasi pada efisiensi investasi.

\section{REFERENSI}

Amrullah, Zidni, \& Fatima, Elza. (2015). Pengaruh Kualitas Laporan Keuangan dan Debt Maturity Terhadap Efisiensi Investasi Perusahaan di Indonesia. Skripsi .Fakultas Ekonomi dan Bisnis Universitas Indonesia.

Apriliani, Anita Nur. (2012). Kajian Kualitas Pelaporan Keuangan Second Order Terhadap Asimetri Informasi. Accounting Analysis Journal, 1(1), 21-26.

Badan Pusat Statistik. (2017). Laju Pertumbuhan PDB Sektor Pertambangan Tahun 2012-2016 dan Laju Pertumbuhan PDB Indonesia Tahun 2016. www.bps.go.id.

Biddle, G.C., \& Hilary, G. 2006. Accounting Quality and Firm-Level Capital Investment. The Accounting Review, 81, 963-982.

Biddle, G.C., Hilary, G., \& Verdi, R.S. (2009). How Does Financial Reporting Quality Relate to Investment Efficiency? Journal of Accounting and Economics, 48, 112-131.

BP Statistical Review of World Energy (2015). London.

Bushman, R. and A. Smith. (2001). Financial Accounting Information and Corporate Governance. Journal of Accounting and Economics, 32, 237-3.

Bushman, R. M., \& Smith, A. J. (2003). Transparency, Financial Accounting Information, and Corporate 
Governance. Financial Accounting Information and Corporate Governance. Economic Policy Review, 9(1), 65-87.

Bushman, R. M., Piotroski, J. D., \& Smith, A. J. (2011). Capital Allocation and Timely Accounting Recognition of Economic Losses. Journal of Business Finance \& Accounting, 38(1-2), 1-33.

Butar, Sansaloni Butar. (2015). Dampak Kualitas Laporan Keuangan, Regulasi Pengendalian Internal, dan Keterbatasan Keuangan Terhadap Inefisiensi Investasi.Jurnal Akuntansi dan Keuangan, 17(1), 57-70.

Chen, Fen, Li, Qingyuan, \& Wang, Xin. (2011). Financial Reporting Quality and Investment Efficiency of Private Firms in Emerging Markets. The Accounting Review, 86, 1255-1288.

Cohen, Daniel A. (2006). Quality of Financial Reporting Choice: Determinants an Economic Consequences. http://papers.ssrn.com.

Dechow, P. \& Dichev, I., (2002). The Quality of Accruals and Earnings: The Role of Accrual Estimation Errors. The Accounting Review, 77, 35-59.

Edvandini, Levinda., Subroto, Bambang., Saraswati, \& Erwin. (2014). Telaah Kualitas Informasi Laporan Keuangan dan Asimetri Informasi Sebelum dan Setelah Adopsi IFRS. Jurnal Akuntansi Multiparadigma, 5(1), 1-169.

Fanani,Zaenal. (2009). Kualitas Pelaporan Keuangan: Berbagai Faktor Penentu dan Konsekuensi Ekonomis. Jurnal Akuntansi dan Keuangan Indonesia, 6(1), 20-45.

Francis, J., R. LaFond, P. Olsson, \& K. Schipper. (2005). The Market Pricing of Accruals Quality. Journal of Accounting and Economics, 39, 295327.

Gomariz, M. Fuensanta Cutillas, \& Ballesta, Juan Pedro Sanchez. (2013). Financial Reporting Quality, Debt Maturity and InvestmentEfficiency. Journal of Banking \& Finance, 40, 494-506.

Howe, J., \& Lin, Ji-Chai. (1992). Dividend Policy and The Bid-Ask Spread: An Empirical Analysis. Journal of Financial Research, 15, 1-10.

Indriani, Rini, \& Khoiriyah, Wahiddatul. (2010). Pengaruh Kualitas Pelaporan Keuangan Terhadap Informasi Asimetri. Simposium Nasional Akuntansi XIII Purwokerto 2010. Universitas Jendral Soedirman Purwokerto.

Ivan, Priyakusuma. (2013). Pengaruh Kualitas Laporan Keuangan terhadap Efisiensi Investasi Perusahaan. Skripsi. Fakultas Ekonomi Universitas Indonesia. Jensen, M.C., \& W.H. Meckling. (1976). Theory of The Firm: Managerial Behaviour, Agency Cost and Ownership Structure. Journal of Financial Economics, 3(4), 305-360.

Komalasari, Puput Tri, \& Permana, I Gede Adi. (2015). Kualitas Laba dan Pengaruhnya Terhadap Keputusan Investasi.Jurnal Ekonomi dan Bisnis, $X X V, 125-134$.

Kothari, S.P., Leone, A.J., \& Wasley, C.E. (2005). Performance Matched Discretionary Accrual

Measures. Journal of Accounting and Economics, 39, 163-197.

Kusuma, Tifany., Agusti, Restu., \& Azhar L, Al. (2014). Pengaruh Kualitas Pelaporan Keuangan, Kepemilikan Institusional, dan Ukuran Perusahaan Terhadap Asimetri Informasi pada Perusahaan Perbankan yang Terdaftar di BEI Tahun 2008-2012. Jurnal Online Mahasiswa (JOM) Bidang Ilmu Ekonomi, 1(1), 1-15.

Leuz, C., \& Verrecchia, R. E. (2000). The Economic Consequences of Increased Disclosure. Journal of Accounting Research, 38, 91-124.

Lingmin, Xie. (2013). How Does Asymmetric Information Relate to Investment Efficiency? Evidence from Analysts' Earnings Forecasts and Daily Stock Trading. http://commons.ln.edu.hk.

Ma, Tao. (2012). Financial Reporting Quality and Information Asymmetry: Evidence from the Chinese Stock Market. https://researchgate.com.

Mc Nichols, M.F., \& Stubben, S.R. (2008). Does Earnings Management Affect Firms' Investment Decisions? The Accounting Review, 83(6), 15711603.

Nurcholisah, Kania. (2016). The Effect of Financial Reporting Quality on Information Asymmetry and Its Impacts on Efficiency Investment. International Journal of Economics, Commerce and Management, 4(5), 838-850.

Nurwa, Risha Aristiani, \& Purwanto, Agus. (2015). Pengaruh Kualitas Laba Akuntansi Terhadap Efisiensi Investasi Perusahaan dengan Risiko Litigasi Sebagai Variabel Moderating. Diponegoro Journal of Accounting, 4(3), 1-11.

Pratiwiningsih, Fajar. (2017). Pengaruh Kualitas Pelaporan Keuangan Terhadap Informasi Asimetri Pada Perusahaan Makanan dan Minuman di BEI Tahun 2010-2015. Jurnal Akuntansi dan Pajak, 18(1), 57-71.

Putri, Juwita Kusumaning. (2014). Faktor-faktor yang Memengaruhi Kualitas Pelaporan Keuangan serta Pengaruhnya Terhadap Efisiensi Investasi pada Perusahaan Go Public. Skripsi. Fakultas Ekonomi Universitas Islam Sultan Agung, Semarang.

Rahmawati, Annisa Dwi, \& Harto, Puji. (2014). 
Analisis Pengaruh Kualitas Pelaporan Keuangan dan Maturitas Utang Terhadap Efisiensi Investasi. Diponegoro Journal of Accounting, 3(3), 1-12.

Sakti, Alisya Misitama, \& Septiani, Aditya. (2015). Pengaruh Kualitas Pelaporan Keuangan dan Jatuh Tempo Utang Terhadap Efisiensi Investasi. Diponegoro Journal of Accounting, 4(2), 1-10

Santoso, Ari Budi. (2012). Pengaruh Kualitas Pelaporan Keuangan Terhadap Asimetri Informasi dengan Ukuran Perusahaan sebagai Pemoderasi pada Perusahaan Manufaktur di BEI. Jurnal Ilmiah Mahasiswa Akuntansi Universitas Katolik Widya Mandala Surabaya, 1(4), 32-37.

Sari, Luh Indah Novita, \& Suaryana, I. G. N. Agung. (2014). Pengaruh Kualitas Laporan Keuangan pada Efisiensi Investasi Perusahaan Pertambangan. Jurnal Akuntansi Universitas Udayana, 8.3, 524-537.
Setiany, Erna, \& Wulandari, Ayu. (2015). Kualitas Pelaporan Keuangan dan Asimetri Informasi di Industri Manufaktur Indonesia. Jurnal Bisnis dan Ekonomi, 6(2), 17-24.

Setyawati, Lucia Jeni. (2015). Kualitas Informasi Pelaporan Keuangan: Faktor-faktor Penentu dan Pengaruhnya Terhadap Efisiensi Investasi. Jurnal Ekonomi dan Bisnis Airlangga, 25, 186-196.

Solimun. 2010. Analisis Multivariat Pemodelan Struktural Metode Partial Least Square- PLS. Malang: CV. Citra.

Wang, Fusheng, Zhu, Zhibiao, \& Hoffmire, John. (2015). Financial Reporting Quality, Free Cash Flow, Investment Efficiency. http://www.shsconferences.org

Virginia, Sheila, Elizabeth Tiur Manurung, \& Muliawati. (2012). Pengaruh Pengumuman Earnings Terhadap Abnormal Return Saham. Jurnal Administrasi Bisnis, 8(1), 1-20. 